\title{
The Supernatural Beings of Belief Legends - Old Fears in a New Context ${ }^{*}$
}

This paper examines the use of belief legends about witches, werewolves, and fairies at open-air festivals in Croatia today. At such events, traditions based on belief legends are invented with the idea of enriching local tourism not only as a source of income but also as a medium through which they portray their local identity. Additionally, the author argues that the concept of fear plays a significant role in the entire process. Visitors face the fear invoked by supernatural concepts, but within the monitored and controlled festival environment, which this helps them overcome their fears and learn how to control them. Furthermore, the author argues that people are increasingly turning toward learning and knowing about supernatural beings of belief legends because they offer an attractive explanation for the functioning of the current world and afterlife.

KEYWORDS: legends, witches, fairies, festivals, invention of tradition, identity

\section{INTRODUCTION}

In the mid- $19^{\text {th }}$ century, towards the end of his shorter study devoted to fairies, Croatian historian, writer, and politician Ivan Kukuljević Sakcinski stated that such beings had become less common in the stories of the Croatian rural population (Kukuljević 1851: 100). Over a century later, Croatian folklorist Maja Bošković-Stulli focused her research on belief legends about different supernatural beings, and, echoing Kukuljević, noted that such stories (i.e., belief legends) had become less frequent and, though recently they could have been found in the field, they now belonged to the past (Bošković-Stulli 1991: 125).

My field research, conducted over the last 15 years in rural areas around Croatia, allowed me to attest that there was a smaller number of groups and individuals who knew or wanted to talk about fairies, witches, werewolves, ${ }^{1}$ and other such beings. During the field research that I conducted together with my students in 2014 at Žumberak, a mountainous area of Croatia distant from major thoroughfares, our interlocutors often remarked that today, at the beginning of the $21^{\text {st }}$ century, "primitive" stories no longer exist and that people have

\footnotetext{
* This paper has been fully supported by the Croatian Science Foundation under the project Narrating fear: From Early Records to New Orality [project number IP-06-2016-2463].

1 In Croatian belief legends, the term werewolf is used for an undead person who, after their death, returns among the living to seek redemption for their sins. Most eastern Slavs term such a creature vampire. For more on the werewolf and the vampire, cf. Lecouteux 2013, Šešo 2016: 41-58; 41-58.
} 
ceased to believe in supernatural beings because their villages are now equipped with schools, churches, asphalt roads, telephone connections, and electricity, which is why the "superstitions" that we were researching in their villages had disappeared (cf. Fijala 2017, Žagi 2017). Similarly, during the research of traditional beliefs and belief legends about supernatural beings, which I conducted on several occasions in the period between 2003 and 2008 in the Dalmatian Hinterland and Istria, ${ }^{2}$ I recorded many instances of witches, $m o ̀ r a,{ }^{3}$ i.e., nightmare witches, fairies, and werewolves (Šešo 2016). However, in conversation with my interlocutors, I noticed that in their testimonies they often felt the need to clarify that nowadays there were fewer or almost no such beliefs and belief legends because they now had explanations for the phenomena that used to be explained by the existence of supernatural beings in the past. Thus, some of the interlocutors attributed the current lack of belief legends about the vrimenjak, an individual with the supernatural ability to predict the weather, to the existence of educated meteorologists who nowadays perform this task. Beliefs in characters such as krsniks, ${ }^{4}$ who, according to belief legends, could heal people, have been substituted by going to the doctor, while belief legends about the macic ${ }^{5}$ a dwarf with a red cap who brings wealth to the one who manages to take the cap away from it, have been supplanted by playing games of chance. According to some interlocutors, belief legends about the undead, such as werewolves, disappeared with the arrival of electricity and artificial illumination to the village, an occurrence that led to the dissipation of the fear of these dark beings (Šešo 2016: 265-266).

According to Lauri Honko, the main characteristic of supernatural beings is inspiring fear, causing fright, and presenting a threat (1962: 118). Some folklorists believe that the fear inspired by belief legends about supernatural beings plays a vital role in shaping and maintaining social norms (cf. Mencej 2017: 390-394, Röhrich 2018: 353, Šešo 2016: 173-188). Numerous belief legends indicate that men used to be afraid of unknown psychic forces that made them do bad and violent things because they believed that such acts might make them turn into werewolves after their death (Šešo 2016: 180). People strived to perform the holy sacrament of baptism on newborn children immediately after birth because they were afraid that the soul of a child who passed before being baptised could turn into storm demons (cf. O’Connor 1991, Polonijo and Šešo 2002). During evening get-togethers, people would tell stories based on belief legends about supernatural beings in order to make the children afraid of wandering outside the village on their own or leaving their houses at night (Šešo 2016: 186-188). Fairy-like beings were said to reward well-behaved and virtuous girls and boys, yet were believed to cause psychological

\footnotetext{
2 Dalmatia is a region in the south of Croatia located between the Adriatic Sea to the west and Bosnia and Herzegovina to the east. Istria is a peninsula located in western Croatia.

3 According to Croatian, as well as many belief legends around Europe, mòra is a demonic being who attacks a human being at night and drains their life's essence. For more on mòra, consult: Marjanić 1999, Šešo 2016: 58-72, Rudan 2016: 241-262.

4 In Croatian belief legends, $k r s n i k$ is an individual/being with supernatural powers who helps their community in the fight against evil forces and the hardships of life. For more on krsnik, consult: Šešo 2002/2003, Bošković-Stulli 2005, Rudan 2016: 166-212.

5 In Croatian belief legends, macić are dwarflike demonic beings who use their supernatural powers to either helps humans or cause them harm. For more on macić, consult: Lozica 2002.
} 
ailments of sinful ones (Šešo 2016: 36). In other words, belief legends about supernatural beings were used to establish rules of good and desirable behaviour, as well as to make potential transgressors of commandments and norms afraid, that is, the main purpose of such belief legends was to keep the sinners in fear (Röhrich 2018: 355).

However, since the $19^{\text {th }}$ century, when Kukuljević alluded to the decline of stories about supernatural beings, several other circumstances that had previously made it possible for supernatural beings to "have an effect," subsequently changed throughout rural Croatia. Evening get-togethers, corn shucking, and other occasions at which folk tales about supernatural beings would be told have almost completely disappeared. Many villages around Croatia have been deserted, while in the majority of the ones that remain, the number of children who would listen to stories about supernatural beings and later maintain and construct a belief system continues to decline. In addition, certain social norms, which the supernatural beings had "helped" to shape, have also changed. Nowadays, it is no longer socially unacceptable to have a child outside of marriage or a romantic relationship without being married; furthermore, Croatian and foreign TV series and films present such situations as a completely normal part of everyday life. Therefore, the liberalisation of socially-acceptable behaviour has contributed to the change of old (and the creation of new) social norms. People are no longer afraid of encountering a supernatural being who will punish them, for example, for having a relationship without being married. Therefore, although supernatural beings of belief legends fulfil multiple social functions and evoke a wide range of emotions (cf. Mencej 2017: 111-120, Šešo 2016: 165-247), we might conclude that without having the ability to incite fear, the supernatural beings disappear.

Nonetheless, though it is possible to observe a trend of decline and disappearance of belief legends about supernatural beings since Kukuljević's time; in reality, they are not the ones that disappear, but rather, their original habitus, i.e., the rural communities, on the one hand, undergoing population decline, and on the other, increasing technological and infrastructural development, hence, changing the chronotope in which we traditionally searched for and observed legends and beliefs. Belief legends and folk beliefs in supernatural beings, therefore, are not disappearing but are rather changing, undergoing transformation and being supplanted by new forms. Thus, for example, the weather forecaster or meteorologist has substituted the vrimenjak, while the lottery girl has taken the place of the macić. Additionally, this transformation consequently implies the displacement of folk beliefs and legends from their original environments into a new context. Here, I am referring primarily to the modes of expression of elite and popular culture, such as films, theatre, literature, documentaries, and art exhibitions thematising belief legends and traditional lore about supernatural beings. Belief legends about witches, fairies, werewolves, and other supernatural beings that were present among inhabitants of rural, "traditional" areas, have been "transplanted" to films and serials such as Harry Potter, Dracula, The Twilight Saga, Pan's Labyrinth, and many others. This process of the "transplantation" of belief legends from their "original" environment to that of popular culture also includes the phenomenon, observable in Croatia in the previous decade, of organising festivals dedicated to belief legends, folk tales and beliefs in supernatural 
beings belonging to traditional cultures. This paper aims to explore such festivals in Croatia and to examine the role of belief legends about supernatural beings in this process. In so doing, the paper will focus primarily on the fear-inducing role and characteristics of supernatural beings, since fear is a significant aspect of belief legends (Honko 1962: 118, Röhrich 2018: 355).

\section{CROATIAN FESTIVALS FOCUSING ON SUPERNATURAL BEINGS FROM BELIEF LEGENDS}

In their cultural-anthropological study of festivals in Croatia, Petra Kelemen and Nevena Škrbić Alempijević state that the process of the development of festivals, present in Europe from the $18^{\text {th }}$ century onwards, has occurred in seven waves (Kelemen, Škrbić Alempijević 2012: 56). They assert that, in Europe, the 1970s saw a considerable increase in the number of festivals focusing on elements of tradition, owing to the development of tourism, support to minority cultures, promotion of contemporary artistic creation and openness to different music genres and styles. In Eastern Europe, this trend only began to emerge after 1990, when the processes of democratisation of society, which helped strengthen the diverse cultural identities of different social groups, also lead to the increase in the number of smaller, local festivals. During the socialist era, festivals had a pronouncedly ideological function, and they were directed at creating uniform identities, though, even then, traditional culture festivals and events catered to a plurality of needs and identities (Kelemen and Škrbić Alempijević 2012: 62, cf. Ceribašić 2003). The process, which the authors call festivalization, is characterised by a growing number of festivals and the process of creation of festivals as cultural practices. The main goal of organising these festivals is the affirmation of the identity of a particular community, while simultaneously enriching the tourist attraction and attracting more tourists (Kelemen and Škrbić Alempijević 2012: 51, 54).

Observing the dynamics of the festival held since the early 19th century in the Swiss village of Interlaken, which focuses on traditional customs, dances and attire, Regina Bendix offers a similar conclusion, emphasising that traditions are always formed in the present and that the ones who define them at festivals do not concern themselves with whether scholars would define these traditions as original, but rather whether the event will achieve its intended goal (Bendix 1989: 132). The anachronistic and selective conception of tradition, which Bendix detects in relation to the creation of the festival in Interlaken, should be viewed through the "invention of tradition" process. According to Eric Hobsbawm, this phenomenon reached its peak towards the end of the $19^{\text {th }}$ century, coinciding with the creation of national states, when, in a quest to form an identity, activities of ritualistic and symbolical nature were used to establish certain values and norms of behaviour. Since rituals are repetitive and performative practices, it was easy to create the impression of continuity with the past, that is to say, with carefully selected segments of the past. Furthermore, where possible, these activities often sought to establish a link with the appropriate segment of the historical past. "Invented" traditions are, therefore, 
a response to new situations, referencing the old in order to construct and establish one's own past (Hobsbawm 2011: 6-7).

From this perspective, Bendix examines festivals focusing on traditional cultures as places where tourists come to observe the intact, "authentic" village culture, which is, in reality, an imaginary construct of what they perceive to be the archetypal manifestation of their own culture (Bendix 1989: 133). Here, Bendix emphasises that some folklorists regard this process only as the commodification of folklore, the exploitation of the local population, and the imitation of rituals performed for profit, leading to the loss of the original meaning of traditional culture (Bendix 1989: 142). Bendix does not deny the economic dimension often present in organising such festivals, but emphasises the importance of understanding the mechanism of tourism in the contemporary world, which is no longer simply an economic phenomenon, but rather, owing to its far-reaching social and cultural influence, a civilisational phenomenon (Bendix 1989: 143). Thus, the local population starts to use tourism not only as a source of income but also as a medium through which they will portray their birthplace as a regional centre, a place imbued with tradition and a haven of patriotic values, which assists them in constructing and improving their image (Bendix 1989: 143). Kelemen and Škrbić Alempijević come to a similar conclusion, pointing out that the main reasons for the popularity of festivals are that they add to the local pride, develop or maintain a local or regional identity, manipulate the image of the community to attract tourists, but also provide recreational and leisure opportunities for the local population. Here, the authors believe that "though they are clearly interconnected with the tourist industry, the festivals are simultaneously much more than mere marketing tools. Their multiple roles surpass the role of merely making profit off culture - they are places where culture is created" (Kelemen and Škrbić Alempijević: 2012: 49-50, 63).

In a broader process of folklorization and retraditionalization, festivals focusing on supernatural beings from belief legends have been on the rise, which this paper examines in the context of Croatia. One of the preconditions for organising such a festival is that a certain location is somehow linked to belief legends or real historical events that have been interwoven with beliefs in supernatural/demonic beings. Thus, for instance, the Ogulin Fairy Tale Festival, held in Ogulin since 2006, partly owes its popularity to the notion that witches gather at the top of the nearby Klek Mountain (Kelemen and Škrbić Alempijević 2012: 185-270). ${ }^{6}$ Zagreb's Upper Town and Tuškanac, ${ }^{7}$ the locations of the burning of those accused of practising witchcraft in the $18^{\text {th }}$ century (Bayer 1969: 524), became the venues of the music festival, Gričevanje, held between 2012 and 2015, while the logo of the festival included a stylised witch's hat. The festival program included music and theatre performances, and in its first year, a symbolic burning of the "witches." Since 2006, the Trsat Castle overlooking the city of Rijeka has been the location of Malik Fest - the Festival of Istrian and Kvarner Myths and Legends offering games, workshops

\footnotetext{
6 See: Vile, vještice, divovi i patuljci u režiji Marija Kovača. 2009. https://www.tportal.hr/kultura/clanak/ vile-vjestice-divovi-i-patuljci-u-reziji-maria-kovaca-20090605 (accessed on Jan 16, 2019)

Old quarter outside the medieval city walls.

8 See: Gricevanje. 2015. https://twitter.com/Gricevanje (accessed on Jan 16, 2019)
} 
and performances that introduce the visitors to the traditional culture of the region, more specifically, to belieflegends about supernatural beings. According to the organisers, the impulse to start the festival stems from the numerous Istrian and Kvarner ${ }^{9}$ belief legends about supernatural beings, such as the malik, ${ }^{10}$ witches and mòra. The visitors are thus invited to learn about the characters from "the most ancient stories ranging from the ones who created the world to the ones that will pester you all night long." 11 The northern part of Croatia has also joined this new trend of creating festivals about similar topics. LegenDra - Festival mitova i legendi dravskoga kraja (Festival of Myths and Legends of the Drava Region) has been held in the town of Prelog in Međimurje ${ }^{12}$ since 2017, while its Facebook page includes the following description inviting the visitors to attend:

The festival celebrates the mythical art and the magic of life itself. It is a playground for the imagination - for children and adults alike - offering an escape from daily life and worries. [...] This time, the residents will be the wizards and musicians, artists and storytellers, the wretched coprnice, ${ }^{13}$ lovely fairies and fairy-tale-like beings. ${ }^{14}$

The newest festival inspired by belief legends about supernatural beings - fairies in this case - was held at the beginning of June 2019 in the town of Imotski in the south of Croatia under the title Vilinska Imota Festival. The festival is organised by the local library and the Municipality of Imotski and, in an interview, ${ }^{15}$ the members of the festival team said that it was their wish for the festival to promote the traditions and belief legends of Imotska Krajina ${ }^{16}$ inspired by fairies. They believe the region is known for these traditions, but, previously they were unable to use these unique characteristics for the promotion and strengthening of tourism, which, of course, they hope to rectify by organising this festival. Therefore, they have initiated a two-day festival featuring professional storytellers telling stories about fairies and supernatural beings, an exhibition of photographs about the natural beauty of the region, performances by local klape singers and the performance of the local school children dancing an "invented kolo", danced by the fairies, according to belief legends. ${ }^{17}$

\footnotetext{
9 Kvarner is a coastal region in Croatia located between the peninsula of Istria to the northwest and Dalmatia to the south.

${ }^{10}$ In Croatian belief legends, malik (in addition to macić) is one of the terms for a dwarf that possesses supernatural powers, often wearing a red cap.

${ }^{11}$ See: Malik fest. Festival mitova i legendi Istre i Kvarnera. 2019. http://www.malikfest.com/festival-mitova-i-legendi-istre-i-kvarnera/ (accessed on Jan 16, 2019)

${ }^{12}$ Međimurje is a smaller region in the north of Croatia bordering Slovenia and Hungary and located between the rivers Mura and Drava.

13 A term for witches employed mainly in northwestern Croatia.

${ }^{14}$ LegenDra - Festival mitova i legendi dravskoga kraja. 2017. https://www.facebook.com/events/legendra/359964267773368/ (accessed on Jan 16, 2019)

15 An interview conducted during my visit to this festival in 2019.

${ }^{16}$ Imotska Krajina is a smaller region in Dalmatian hinterland.

17 See: Započinje festival priče i pripovijedanja "Vilinska Imota". 2019. https://radioimotski.hr/2019/05/31/ vilinska-imota-festival-price-i-pripovijedanja/ (accessed on Dec 19, 2019)
} 
The precursor of all of the abovementioned festivals is LegendFest, the oldest festival in Croatia focusing on supernatural beings. LegendFest or the Festival of Legends, Myths and Stories has been held in the Istrian town of Pićan since 2005. The organisers ${ }^{18}$ emphasise that they want to introduce the visitors to the mystical and enigmatic world of traditional Croatian culture and offer fun contents inspired by the mythical and supernatural past of Istria County. ${ }^{19}$ For that purpose, each year the music, dance and theatre performances, exhibitions and lectures by experts and connoisseurs of local history and tradition revolve around a central topic chosen by the organisers. Throughout 14 editions, the central themes of the festivals have mostly focused on legends about supernatural beings. For their first edition, they chose the theme of belief legends about striga ${ }^{20}$ while in the following years the topics were related to beliefs about krsnik, vampires, werewolves, giants, dwarfs, dragons, mòra, orko ${ }^{21}$ as well as supernatural beings that can transform themselves into animals. The great turnout for the festival has encouraged the organisers to create sister events in other Croatian counties, that is, in places linked to the "existence" of supernatural beings or in places where belief legends are an integral part of the local traditional culture. Therefore, since 2014, LegendFest has also been held at Lukavec Castle in Turopolje, ${ }^{22}$ where the beliefs about mogut ${ }^{23}$ and coprnica were chosen as the central topic of the festival. The main topic of LegendFest held since 2016 at Roški Slap in the Krka National Park ${ }^{24}$ is fairy-like beings, while the main topic of the festival held at the Veliki Tabor Castle ${ }^{25}$ since 2018 is once again coprnica $^{26}$ (i.e., witches). LegendFest is the oldest open-air festival with the most branches around Croatia at which the performers and lecturers draw their inspiration from belief legends about supernatural beings. According to the organisers, the visitor turnout at LegendFest increases year after year; in the last two years, the festival has recorded approximately 15,000 visitors. ${ }^{27}$

From this brief overview of festivals, it is possible to conclude that certain historical events, and, more importantly, the belief legends of the local community about supernatural beings provided the initial impetus for the creation of the festivals. Characters

\footnotetext{
${ }^{18}$ The festival is organized by the association Val kulture, whose president Igor Zidarić hails from Pićan.

${ }^{19}$ For more on LegendFest, its programs and content in more detail, visit: LegendFest. 2019. http://legendfest. $\mathrm{hr} /$ legendfest/ (accessed on Jan 8, 2019).

${ }^{20}$ Striga, Ital. name for a witch, used most commonly in the Croatian coastal area.

${ }^{21}$ According to Croatian traditional beliefs, orko is a demonic supernatural being in the form of a donkey, or less commonly a horse, that appears to a tired traveler at night and carries them off on its back in the direction they do not wish to go. For more on the orko, consult: Lozica 2002, Rudan 2016: 262-273.

${ }^{22}$ Turopolje is a low, flat microregion in the vicinity of Zagreb located next to the river Sava.

${ }^{23}$ According to a traditional belief from the Turopolje region, a mogut is a person/being with supernatural powers that can transform into a pig or a giant to help pig farmers from their village find acorns. In order to ensure the wellbeing of their own community, they confront the mogut of another community/village, which then suffers hardship if its mogut is defeated (Chloupek 1953).

${ }^{24}$ Krka National Park comprises the waterfalls and lakes on the river Krka in the vicinity of the Dalmatian town of Šibenik.

${ }^{25}$ The Veliki Tabor Castle is an early medieval castle located in the hilly landscape in northwestern Croatia.

${ }^{26}$ This paper does not cover the LegendFest held in 2018 at the Veliki Tabor Castle since the paper is based on the research conducted in 2017 comprising the festivals in Lukavec, Roški Slap and Pićan.

${ }^{27}$ LegendFest. 2019. http://legendfest.hr/legendfest/ (accessed on Jan 8, 2019).
} 
such as witches, vampires, giants and dwarfs influence the choice of festival topics, which then inspire numerous entertainment and cultural-educational events that the visitors attend both for fun and to learn about local traditions and folklore peculiarities, which are the foundation of cultural identity. Furthermore, the festival side programs regularly include offerings of the local gastronomy, a chance to purchase handicraft products, participate in local traditional games, and demonstrations of local trades. In such an ambience, supernatural beings are one of the themes presented as well. Along with other festival programs, they serve as bait for the visitors who want to learn about the history, tradition, and local identity to which the organisers refer when promoting the events and which are referenced in the very names of these festivals. In this context, the belief legends about supernatural beings play their part in enriching local tourism and profiting from it, but they also contribute to establishing and defining one's identity. However, it is important to note that commodifying belief legends about supernatural beings at festivals creates a new tradition and a new past, that is, "[...] the local events and personages, myths and narratives are ritualised and reconfigured by festivals; the celebrations prompt us to remember the past - namely, the selected past retold via the festival" (Kelemen, Škrbić Alempijević 2012: 191). In other words, belief legends about supernatural beings that are encountered in the stories of professional storytellers, in music and theatre performances, lectures, costumed actors and reenactors, photographs and other festival contents, are in reality interpretations, additions, and creations of belief legends, that is, "invented" traditions. These are not the traditions, history or belief legends as defined by scholars and experts, but rather the traditions, history and legends subjectively perceived by members of society - the ones organising the festivals and the ones visiting them. In the process, as the supernatural beings from belief legends are placed within the festival space where they are moulded according to the needs of the organisers and the visitors, this paper wishes to examine what happens to their element of fright and their fear-inducing features.

\section{THE FRIGHTFUL (AND FEAR) AT LEGENDFEST}

In order to provide answers to these questions, I conducted initial field research during LegendFest held in late May 2017 at Lukavec Castle and the surrounding area in Turopolje. ${ }^{28}$ During the festival, the visitors had the opportunity to encounter actors costumed as witches, devils, vampires, and other demonic beings whose appearance, the sounds they produced, and the noise they made scared both adults and children. Inside the castle itself, the visitors, or rather their children, entered a low, cramped room with the sign on the door that said coprnički rešt (prison for witches) [Fig. 1]. Inside the room, the visitors could spend several moments among artificial human skulls and animal bones aglow

\footnotetext{
${ }^{28}$ In 2017, LegendFest in Lukavec in Turopolje changed organizers and was renamed to Perunfest. The Festival of Forgotten Stories and Folk Tales. Based on the evaluation of the author of this paper, who visited the festival in Lukavec both before and after the change, the content and the appearance of the festivals has not changed considerably compared to the period when it used to be called LegendFest.
} 
with red light, which was a recreation of the atmosphere of the space where women accused of witchcraft had been confined. On the first floor of the castle, inside a dark room with low green lights, the organisers placed a coffin with a person wearing a witch's costume. When any of the visitors approached the coffin, the dead witch would suddenly "come to life" scaring everyone in the room, especially the children. After this, she would invite whoever was interested to take her place and lie in the coffin and during my observation of this "performance," I noticed that very often the parents would try to persuade their children to do so [Fig. 2]. At one moment, one of the fathers closed his daughter inside the coffin while the costumed witch sat on the lid so the child could not get out. After the child started hitting the lid from inside and yelping, the father freed his daughter, who was visibly shaken and on the verge of tears. A macabre atmosphere dominated in other rooms in the castle as well, produced by lighting, renditions of demons, skulls, bones, a cradle with a doll inside, old furniture and the recording of muffled screams that could be heard around the castle [Fig. 3]. The area around the castle was also decorated to incite a sense of fear or dread in the visitors, or at the very least to not leave them indifferent. In the nearby woodland area, there were mannequins of demonic beings hanging from the branches, the employees of the festivals walked around dressed in black with blood-stained makeup on their faces, while behind a wooden door set up for the occasion in the woods, costumed devils were scaring the children

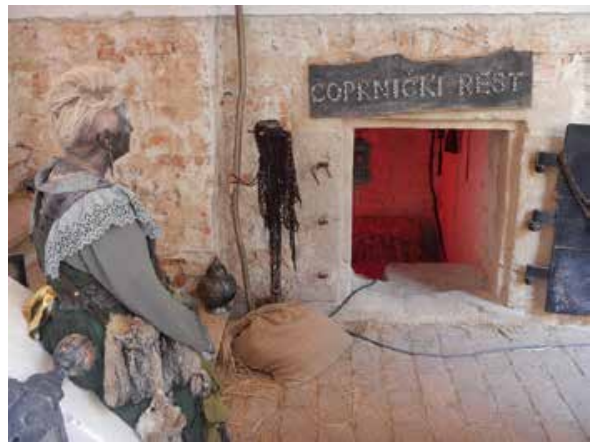

Fig. 1. Prison for witches. LegendFest, Lukavec, Croatia, 2017. Photo by Luka Šešo.

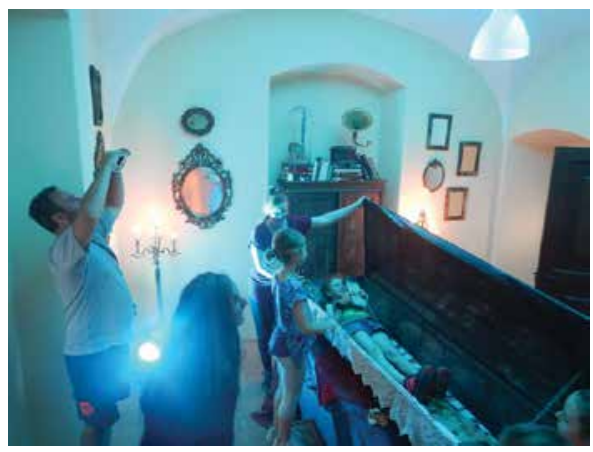

Fig. 2. Children laying in the coffin. LegendFest, Lukavec, Croatia, 2017. Photo by Luka Šešo.

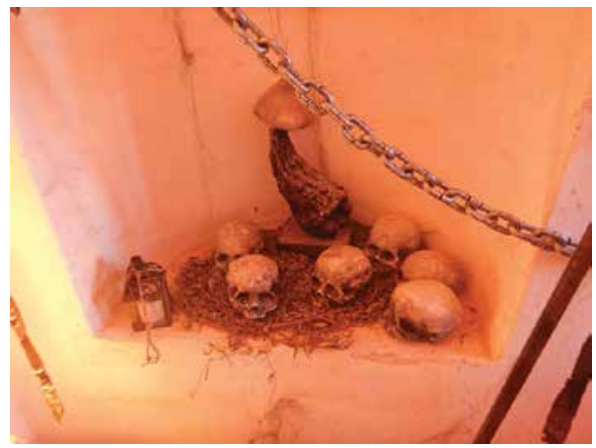

Fig. 3. A macabre atmosphere. LegendFest, Lukavec, Croatia, 2017. Photo by Luka Šešo. by loudly tugging their chains. In such an atmosphere, the visitors consumed food and beverages, listened to stories about supernatural beings and were entertained by different dance and drama acts. As the day progressed, the darkness intensified the dramatic effect of the staged scenes. The climax of the festival was the burning of a large dragon made out of hay dominating the front entrance to the festival area. 
This concise description of the festival in Lukavec leads us to wonder why visitors are attracted to such a fear-inducing atmosphere and imagery. Following an observation of some of the contents of the festival, it may be concluded that, in terms of its visual appearance and content, the festival emphasises the elements that induce dread. The visitors, especially children, were noticeably afraid, while the (costumed) supernatural beings and the staged scenes in certain instances made them tense and anxious. According to Lars Svendsen, human beings need to experience a full range of emotions, and fear allows us to break free from the routine and monotony of our daily lives. Most people interrupt and assuage the tedium of daily routine by watching horror films or by visiting the abovementioned festivals. It is not uncommon for boredom to make us move towards the transgression of boundaries, while fear and the frightful represent the counterbalance to the tedium of daily life (Svendsen 2010: 98). However, it needs to be pointed out that horror films or horror games, as well as the festivals that I have cited, also represent something we can simply walk away from. These are spaces and environments in which, to a large extent, it is possible to supervise fear. We encounter fear in its tamed form; therefore, it does not wound us (Svendsen 2010: 98). We experience what we might term a "fear substitute" - we experience real fear, but we are not in any real danger. The violent and frightful fictions provide an appropriate medium for the articulation and processing of our emotions. Children can also benefit from this by learning to overcome their fear (Svendsen 2010: 98). According to Sara Ahmed, turning away from the object of fear means turning towards the objects of love, which, in an ideal situation, become a defense mechanism against death with which fear supposedly threatens us. In other words, the crucial element of contemporary, deliberate encounters with fear is not the fear itself, but rather the realisation that we can step away from it into a safe environment (Ahmed 2014: 67). As psychologist Dolf Zillmann explains when analysing the effects of suspense in dramatic works (1996), the satisfaction of the audience lies in the controlled stepping away from fear, in successfully escaping the frightful and violent. This is confirmed by the research conducted by Cynthia Hoffner and Keneth Levine that examines the relationship between horror films and pleasure of the viewer (2005: 227). In this mechanism of staging controlled horror, the supernatural beings from belief legends play an important role, and they have become the central point of festivals such as LegendFest. Lutz Röhrich also affirms that most belief legends are imbued with a fear of demonic beings, of death, of the dead, while the supernatural world is perceived as a threat (Röhrich 2018: 352-365).

From that point of view, belief legends are an important source of information when examining the changes of consciousness that have occurred over the past 150 years. Since then, human beings have increasingly placed the world under their control; however, they have done so at the expense of the supernatural world, which in belief legends stands up to us as something highly strange and as something of which we should be afraid. Therefore, human fear has moved on to other areas nowadays. Fears become disintegrated, yet other fears take their place, or rather, old fears appear in new guises (Röhrich 2018: 365).

The "new guise" Röhrich is referring to can also be recognised at festivals in Croatia that include the presence of fear of supernatural beings from belief legends. That is, if we focus on some of the scenes from the brief description of LegendFest at Lukavec, it 
is clear that it foregrounds precisely the beings and situations to which Röhrich is referring. By interacting with actresses dressed as witches and visiting the prison in which the supposed witches used to be incarcerated, the visitors encounter a representation of a female character that is the embodiment of numerous fears. They are also faced with an attempt to find the "culprit" for the culturally mediated fear, since, in Croatian belief legends, witches are linked to the causes of inexplicable accidents, afflictions, and illnesses. They are the victims of neighbourhood quarrels, jealousy, envy, and dislike (cf. Mencej 2017: 111-211, Šešo 2012). "Believing in witches reveals the fear of women who know more, the women who have greater power, and of female sexuality" (Röhrich 2018: 356).

The actors who jump out of coffins make the visitors feel afraid of the restless dead, which is another central construct of belief legends. Such beliefs reveal less about the dead and more about ourselves, that is, about our attitude towards death and the restless dead, who return to this world because of their sinful and in many ways problematic earthly life. The characters of the devil who frighten the children around the festival area, also incite the fear of the being that appears to the transgressors of commandments and norms. Finally, the symbolic burning of the straw dragon that takes place at the end of the festival is a symbol of victory and of overcoming a powerful opponent that induces fear and is the embodiment of chaos that threatens both the divine and human kind (see. Röhrich 2018: 355-357). The supernatural beings from belief legends that we encounter at festivals such as LegendFest still preserve their role of inciting fear: "Among stories there are those that wish to produce fear, as well as those whose primary function is to overcome fear. The two tendencies are interconnected because fear causes counter-reactions" (Röhrich 2018: 364). Deliberately producing fear to control and overcome it represents one of the key functions of belief legends about supernatural beings. In order to confront our fears and overcome them more easily, belief legends serve to articulate our instances of fear and find explanations for them, thus removing their ability to produce dread: "By featuring embodied supernatural beings, belief legends have the potential, to a certain degree, to dispel irrational, objectless fears" (Röhrich 2018: 354). A similar mechanism occurs at festivals, except, in addition to listening to stories about supernatural beings, the visitors also encounter their embodiments in the form of masked actors. The visitors are confronted with the fear of death by being enclosed in a coffin, the encounter with the demonic and the supernatural is simulated by the prison for witches and the devil's door in the woods. These instances offer the visitors a chance for an encounter with the frightful, while providing the possibility of relieving and assuaging their fear by reserving the option of instantly leaving such frightening and intense places and situations.

However, let us examine the other role of fear caused by supernatural beings from belief legends, according to Röhrich, and that is to deliberately incite fear in transgressors of social norms and customary law. Specifically, deliberately provoking the fear of supernatural beings contributes to the compliance with set social norms and, consequently, to the conservation of the hierarchy of power. Fear instills a sense of guilt and the need for redemption, thus safeguarding an individual from the punishment of the supernatural world (Röhrich 2018: 353). Within this mechanism of inducing fear, it is vital to examine the notion of belief "[...] the presence of which is felt in any form of legend. [...] Directly or 
indirectly, a belief legend almost without exception implies that at some point, someone, somewhere: 'a neighbor', 'an old lady', 'grandpa', 'someone', 'some other people', 'a long time ago' believe or believed in its message” (Dégh and Vázsonyi 2018: 347). In other words, fear caused by supernatural beings from belief legends can affect a society or an individual only if it is believed that these beings could, at some point and in some way, cause actual harm to someone.

\section{FROM AGENTS OF FEAR TO OBJECTS OF AWE}

In order to research the presence of belief legends and beliefs in supernatural beings at festivals and to observe the concept of fear within them, I conducted short surveys during two other editions of LegendFest held in 2017. One edition, held in early July at Roški Slap in the Krka National Park, focused on belief legends about fairies. The other LegendFest, held in late July in the Istrian town of Pićan, was dedicated to belief legends about the mòra. ${ }^{29}$

Further prompted by the reasoning of the organiser whose website stated that they wished to acquaint the visitors with traditional beliefs of our ancestors at the time when the supernatural beings "were creating the world" and when there was "mythical art and magic of life itself," I included the question: "What do you think is the reason that older generations believed in fairies/mòra?" The answer to this question was left blank by $10 \%$ of respondents, while the rest of the answers can be grouped into two categories. In the first, smaller group, $36 \%$ of respondents agreed that the reason was superstition, a "primitive" way of thinking or a lower degree of education of older generations. However, more than half of the respondents (53\%) offered other explanations that can further be divided into two subcategories. The first subcategory comprises short answers in which the respondents attribute the existence of traditional beliefs of older generations to two concepts that we have analysed earlier in the paper - to cause fear and derive enjoyment from something scary and unfamiliar, as well as to work through intense emotions:

"For creating fear and entertainment." AV12
"Because they wanted to create entertainment and cause fear." AV11
"It was their way to scare and intimidate people. That's how their elders
taught them." AM22
"They believed in what frightened them." AV27

\footnotetext{
${ }^{29}$ The survey included a total of 80 visitors to the festival who participated in the research voluntarily. During the edition of LegendFest at Roški Slap, 40 visitors completed the survey and the same number completed the survey at the festival in Pićan. For the purposes of this paper, only the answers to two survey questions are analyzed here, while the survey contained ten questions and included topics not discussed in this paper. The completed questionnaires are kept in the author's private archive.

${ }^{30}$ The letters AV refer to the survey on fairies (Roški Slap), while the letters AM refer to the survey on mòra (Pićan). The number next to the letters stands for the ordinal number on the questionnaire.
} 


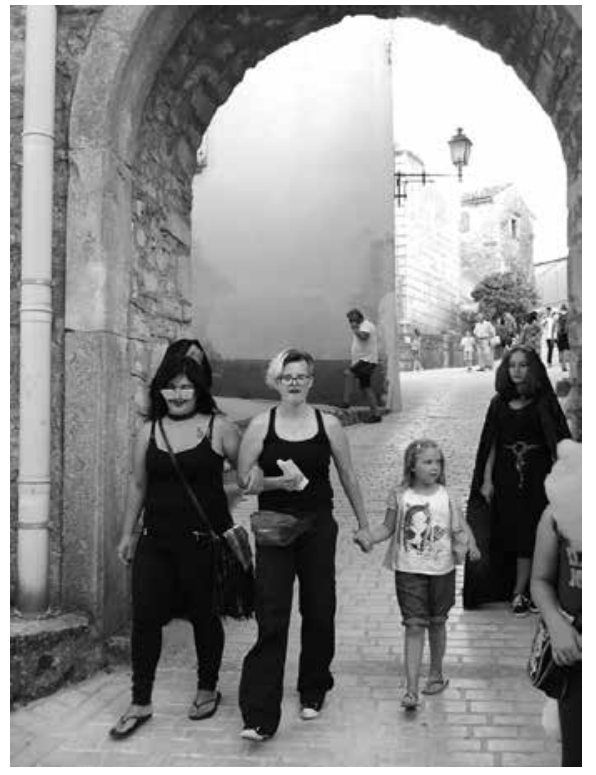

Fig. 4. Visitors dressed as witches. LegendFest, Pićan, Croatia, 2017. Photo by Luka Šešo.
In other words, a portion of the respondents identifies the mechanism of inducing fear as a vital characteristic of the supernatural beings of belief legends. However, frightening someone or inciting fear is not the purpose itself, but rather it is connected to fun, or alternatively, to belief. So what sort of belief is this? Here, it is important to extend the interpretation of fear caused by tales about supernatural beings. Even though fairies, witches, mòra, vampires, werewolves and other demonic/supernatural beings are frightful and cause people to be afraid, when belief legends about them are being taught in a fun way, as older generations used to do at evening get-togethers or as it is today done at festivals, they also inspire a sense of awe. Therefore, it is not (only) a question of being afraid of them, but (also) of feeling awe towards supernatural beings, in other words,

this is a mechanism that contributes to shaping a culturally more demanding system of concepts and beliefs such as myths, cults and religious systems. In controlled environments, the supernatural beings are transformed from agents of fear into objects of awe, while fear is a mechanism that inspires a sense of respect towards them. Why members of a community should create (or renew) their sense of awe towards supernatural beings is best expressed by examples in the second subcategory of answers:

"Out of a need to explain the world around them." AV13

"They were in touch with nature; they were farmers so they sought solace and faith in these beings." AV3

"Because they needed to believe in the existence of something larger than themselves." AV14

"In order to explain certain natural occurrences, but also to enrich their life with stories." AV15

"Perhaps because they believed in something larger and more powerful than themselves." AV16

"Because they do exist and they were more connected to nature so they could see them." AM11

"Because they wanted to explain reality." AM13

"Because they are all around us." AM15

"They were in tune with the spiritual state of the world." AM12

"Because they tried to explain the world around them somehow and the different phenomena that exist in it." AM10 
It is evident from these examples that some of the respondents/festival visitors concluded that our ancestors needed the belief in supernatural beings in order to explain the world around them. The belief in supernatural beings, however fear-inspiring they may seem, aids in grasping our cosmic system, the phenomena and events one cannot influence, as well as the social hierarchies and injustices of the material world. Such beings and their powers inspire human beings with a sense of awe, which is based on cosmic fear that needs to be differentiated from "regular" fear, as Noel Caroll asserts. In attempting to understand why literature, film, and other forms of popular culture are drawn to demonic and supernatural beings, Caroll, who takes his inspiration from writer Howard Phillips Lovecraft and philosopher Rudolf Otto, concludes:

Humans, it appears, are born with a kind of fear of the unknown which verges on awe. Thus, the attraction of supernatural horror is that it provokes a sense of awe which confirms a deep-seated human conviction about the world [...] it contains vast unknown forces. [...] Fear itself is distasteful and would naturally be avoided; but cosmic fear is not simply fear, but awe, fear compounded with some sort of visionary dimension which is said to be keenly felt and vital (Caroll 1990: 163).

Another way of explaining the attraction of horror - one that may be connected with elements of the religious account - is to say that horrific beings - like deities and daemons - attract us because of their power. They induce awe. In one mode of speaking, it may be said that we identify with monsters because of the power they possesses - perhaps monsters are wish-fulfillment figures (Caroll 1990: 167-168).

May we, therefore, conclude that some visitors attend festivals like LegendFest because of supernatural beings that have the power to explain the world in its entirety and to explicate the interconnections between natural and supernatural forces and occurrences? Do some visitors, at a time of social and moral crises, believe in the need to reintroduce certain hierarchies and norms whose authority derives from the supernatural, and to feel a sense of awe towards the inexplicable and other-sided just as, according to their opinion, older generations used to? The answer to these questions could be provided by the answers to the second survey question, which asked the respondents whether they believed that fairies and fairly-like beings (Roški Slap) and mòra and witches (Pićan) still existed, and if they thought they did to explain briefly why they thought so. The results indicate that $40 \%$ of respondents expressed a belief in the existence of mora and witches, and as many as $51 \%$ of respondents expressed belief in the existence of fairies and fairy-like beings. Explaining their answers to the question whether they believed in the existence of supernatural beings, it was evident that they too perceive the supernatural beings in connection to the limitations of their daily life, or rather, that they find the current explanations about nature inadequate:

"I do not think they exist in the form of beings, but rather as occurrences that happen to us and have an effect on us." AV27

"I think that fairies are representatives of nature and what we can expect from it. It is magnificent, but sometimes also horrific and cruel. I believe in fairies as energy and the soul of every forest being." AV15 
"It is nice to believe." AV3

"Because everyone needs a glimmer of magic." AV1

"Because nature is magical so magical beings probably reside in it." AV28

"They exist, only in human form." AV17

"Because I believe in the inexplicable, that there is an invisible force, a parallel world... it is impossible for us to be alone." AV9

"They used to exist, so they must still exist today." AV7

"They exist, I think there are both negative and positive ones, whether it is a woman visiting the Shrine in Međugorje or observing the Sabbath!” AM13 "Perhaps they do not exist in the form in which they are represented in legends, but I have had an encounter with them!" AM11

"I believe they exist, but people are simply too preoccupied with other things, so they no longer think about mòra and witches." AM24

The answers to the last question are simply too diverse to allow a straightforward explanation of the respondents' reasons for believing in supernatural beings such as fairies and mòra. For some, they are invisible forces of nature, parallel worlds, or supernatural occurrences affecting us. For others, they are certain individuals (most often women) from the respondents' surroundings whose actions they cannot understand or of which they do not approve. In contrast, some believe that they do not exist in the same form as they used to, but have, paradoxically, experienced an encounter with them, while others find the belief as such to be beautiful or magical and hence necessary. Nonetheless, it is important to note that the respondents adjust their explanations of the existence of supernatural beings to the contemporary world in which they live. Fairies and mòra are no longer (just) demonic beings living in the woods or the neighborhood, but they are also forces of nature, embodiments of invisible energy, parallel worlds, that is, as respondent AV9 notes, they are something "inexplicable," with approximately half of all respondents believing in this "inexplicable" phenomenon.

\section{CLOSING CONSIDERATIONS}

Since the middle of the $19^{\text {th }}$ century, when Kukuljevic remarked on it, the supernatural beings from belief legends have become less common in their "original" environment, which is understood to be the rural communities that nurture a "traditional" way of life. Nevertheless, this does not imply that the belief legends about supernatural beings have disappeared and are being lost, but rather that they are being transplanted to different forms, such as the recent festivals that this paper has examined in the context of Croatia. At the festivals, as forms of "invented tradition," the beliefs and the supernatural beings from Croatian belief legends are commodified and presented alongside other tourist and consumerist products and, as such, are drafted to participate in the process of boosting the tourist offer. At the same time, the supernatural beings from belief legends, together with the rest of the festival "offer" based on traditional culture, acquire an identity-forging 
role within the process that wishes to create affective "bonds" between the visitors and the idealised, mythical world of the selective past. In contemporary society, doubts about the benefits of economic development and the appearance of "quality of life" indices have led to the rediscovery and the idealisation of the "traditional" way of life in a community based on solidarity. Within both rural and urban communities, celebrations are organised in order to make individuals feel less alienated from society (see Kelemen and Škrbić Alempijević 2012: 56). On such occasions, the visitors encounter supernatural beings from belief legends that make it possible to express one's own anxieties and insecurities caused by new changes in society, articulate one's own fears of the unknown and convey one's hopes for economic stability (see Valk 2008: 236). In this context, supernatural beings today still preserve their role as fear-enticing and frightening beings, by means of which individuals learn to face their own limitations, life's threats and unpredictable scenarios. The frightening scenes and the elements of horror that are often a feature of festival programs additionally attract visitors, especially younger generations, because these allow them to face the frightening (and their fear) in a controlled environment, in which they are able to distance themselves from it and thus learn to overcome it. However, in the context of supernatural beings, in addition to the notion of fear, it is important to consider the concept of awe. That is to say, I believe that festival programs in which the visitors come in contact with frightening supernatural beings contribute to the creation or renewal of a sense of awe towards such beings and their powers. Creating a sense of awe strengthens the belief that they used to be able to and can still use their powers to influence the world we live in, hence inspiring the quest for answers to numerous questions about the origin of the universe and about ourselves.

Moreover, the conducted research indicates that a great number of visitors to the festivals in Croatia described in this paper identifies precisely the role of providing explanations as the reason for believing in supernatural beings. They express that our ancestors employed supernatural beings to explicate the world and provide answers to existential questions, but they also state that they themselves believe in their existence and their place within the universal order. The desire to come to know the supernatural, the mythical and the fantastic, as well as the popular and scientific works that stem from this desire, "become increasingly pronounced in times of crises and in pivotal moments for the community" (Lozica 2007: 141). Over the last several decades, we have been faced with what might be termed the retraditionalization of society and the remythologization of contemporary culture and science (Lozica 2007: 149). Hence, within contemporary Croatian society, people continue to draw inspiration from supernatural beings from belief legends in order to configure anew the moral norms and rules of behaviour and to organise the world around them. The interest in supernatural beings from belief legends is, in fact, a reflection of the aspirations to seize control over the problems in the society and to bring structure to everyday life. 


\section{WORKS CITED}

Ahmed, Sara, 2004: The Cultural Politics of Emotion. Edinburg: Edinburg University Press.

Bendix, Regina, 1989: Tourism and Cultural Displays Inventing Traditions for Whom? The Journal of American Folklore 102/ 404, Fairfax, Virginia, 131-146.

Bošković-Stulli, Maja, 1991: Pjesme, priče, fantastika. Zagreb: Nakladni zavod Matice hrvatske i Zavod za istraživanje folklora.

Carroll, Noël, 1990: The Philosophy of Horror or Paradoxes of the Heart. New York and London: Routledge.

Ceribašić, Naila, 2003: Hrvatsko, seljačko, starinsko i domaće: Povijest i etnografija javne prakse narodne glazbe u Hrvatskoj. Zagreb: Institut za etnologiju i folkloristiku.

Chloupek, Drago, 1953: Mogut. Zbornik za narodni život i običaje 37, Zagreb, 241-250.

Fijala, Ivana, 2017: Tradicijska vjerovanja u nadnaravna bića Langovog Sambora - stotinu godina kasnije. Šešo, Luka (ed.), Samobor - stotinu godina nakon Milana Langa. Zagreb: Matica hrvatska Ogranak Samobor and Hrvatsko katoličko sveučilište. 161-179.

Dégh, Linda; Vázsonyi, Andrew, 2018: Predaja i vjerovanje. Marks, Ljiljana; Rudan, Evelina (eds.), Predaja: temelji žanra. Zagreb: Institut za etnologiju i folkloristiku. 321-350.

Hobsbawm, Eric, 2011: Uvod: Kako se tradicije izmišljaju. Hobsbom, Erik; Rejndžer, Terens [Hobsbawm, Eric; Terence, Ranger] (eds.), Izmišljanje tradicije. Beograd: Biblioteka XX vek. 5-26.

Hoffner, Cynthia A.; Levine, Kenneth J., 2005: Enjoyment of Mediated Fright and Violence: A Metha-Analyses. Media Psychology 7/2, London, 207-237.

DOI: 10.1207/S1532785XMEP0702_5

Honko, Lauri, 1962: Gaisterglaube in Ingermanland. FF Communications 185, Helsinki, 5-470.

Kelemen, Petra; Škrbić Alempijević, Nevena, 2012: Grad kakav bi trebao biti. Etnološki i kulturnoantropološki osvrti na festivale. Zagreb: Nakalda Jesenski i Turk.

Križanec-Beganović, Danijela (ed.), 2015: Čarobna družba. Vjerovanja u nadnaravna bića u Podravini. Zagreb: Etnografski muzej.

Kukuljević, Ivan, 1851: Bajoslovlje i crkva. Arhiv za povjestnicu jugoslavensku 1, Zagreb, 86-104.

Lecouteux, Claude, 2013: Povijest vampira. Autopsija mita. Zagreb. TIM press.

Lozica, Ivan, 2002: Poganska baština. Zagreb: Golden marketing.

Lozica, Ivan, 2007: U susret drugoj mitologiji. Porod od time: Jokastine kćeri i unuke. Studia Mythologica Slavica 10, Ljubljana, 137-153.

Marjanić, Suzana, 1999: Zaštitna sredstva protiv mòre kao žensko-niktomorfnog demona Treća. 2/1, Zagreb, 55-71.

Mencej, Mirjam, 2017: Styrian Witches in European Perspective. Ethnographic Fieldwork. London: Palgrave Macmillan.

O' Connor, Anne, 1991: Child Murderess and Dead Child Tradition: A Comparative Study. FF Communications 249-250, Helsinki, 5-670.

Polonijo, Ivana; Šešo, Luka, 2002: Dijete pred rajskim vratima: Narodna vjerovanja Južnih Slavena u nadnaravnu manifestaciju duša mrtve djece. Kodovi slovenskih kultura 7, Beograd, 102-130.

Röhrich, Lutz, 2018: Predaja - bajka - narodno vjerovanje: kolektivni strah i njegovo svladavanje. Marks, Ljiljana; Rudan, Evelina (eds.), Predaja: temelji žanra. Zagreb: Institut za etnologiju i folkloristiku, 351-370. 
Rudan, Evelina, 2016: Vile s Učke. Žanr, kontekst, izvedba i nadnaravna bića predaja. Zagreb: Hrvatska sveučilišna naklada.

Svendsen, Lars Fr. H., 2010: Strah. Zagreb: TIM press.

Šešo, Luka, 2002/2003: O krsniku: od tradicijske pojave u predajama do stvarnog iscjelitelja. Studia Ethnologica Croatica 14/15, Zagreb, 23-53.

Šešo, Luka, 2010: Problem istraživanja nadnaravnih bića u hrvatskoj etnologiji i folkloristici. Marjanić, Suzana; Prica, Ines (eds.), Mitski zbornik. Zagreb: Institut za etnologiju i folkloristiku, Hrvatsko etnološko društvo, Scarabeus-naklada, 115-125.

Šešo, Luka, 2012: Which Woman is a Witch? The Stereotypic Notions about Witches in Croatian Traditional Beliefs. Studia Ethnologica Croatica 24, Zagreb, 195-207.

Šešo, Luka, 2015: U potrazi za mitskim svjetovima u suvremenom društvu. Križanec-Beganović, Danijela (ed.), Čarobna družba. Vjerovanja u nadnaravna bića u Podravini. Zagreb: Etnografski muzej u Zagrebu, 64-72.

Šešo, Luka, 2016: Živjeti s nadnaravnim bićima. Vukodlaci, vile i vještice hrvatskih tradicijskih vjerovanja. Zagreb: Naklada Jesenski i Turk.

Valk, Ülo, 2008: Folk and the Others. Constructing Social Reality in Estonian Legends. Lang, Valter; Kull, Kalevi (eds.), Estonian Approaches to Cultural Theory. Approaches to Cultural Theory Series. Volume 4. Tartu: University of Tartu Press, 222-238.

Zillmann, Dolf, 1996: The psychology of suspense in dramatic exposition. Vorderer, Peter; Wulff, Hans Jurgen; Friedrichsen, Mike (eds.), Suspense: Conceptualizations, theoretical analyses, and empirical explorations. Mahwah, NJ: Lawrence Erlbaum Associates, 199-231.

Žagi, Karla. 2017. Društvene i modernizacijske promjene kao bitni elementi slabljenja pripovijedanja o nadnaravnim bićima. Šešo, Luka (ed.), Samobor - stotinu godina nakon Milana Langa. Zagreb: Matica hrvatska Ogranak Samobor, Hrvatsko katoličko sveučilište, 143-159. 


\section{NADNARAVNA BIĆA PREDAJA. STARI STRAHOVI U NOVOM KONTEKSTU \\ LUKA ŠŠSO \\ $\infty$}

Još od sredine 19. stoljeća, kako na to tada upućuje hrvatski povjesničar, književnik i političar Ivan Kukuljević Sakcinski, nadnaravna bića predaja sve su manje prisutna u svojem "izvornom" habitusu pod kojim podrazumijevamo ruralne sredine sa "tradicionalnim" načinom života. Međutim, to ne znači da predaje o nadnaravnim bićima nestaju, da se gube, već se izmiještaju u druge oblike popularne kulture poput suvremenih festivala na kojima se tematiziraju predaje i tradicijska kultura, a koji se u ovom radu motre u hrvatskom kontekstu. Na takvim festivalima, kao svojevrsnim oblicima "izmišljene tradicije”, nadnaravna bića hrvatskih predaja i vjerovanja komodificiraju se i pojavljuju uz druge turistički i konzumeristički oblikovane produkte te tako sudjeluju u procesu razvoja turističke ponude. Ujedno, nadnaravna bića predaja zajedno s drugim festivalskim "ponudama" utemeljenima na tradicijskoj kulturi poprimaju identitarnu ulogu unutar procesa u kojem se posjetitelje želi afektivno "povezati" s idealiziranim, mitskim svijetom selektivne prošlosti. Naime, u suvremenom društvu zbog sumnje u dobrobit ekonomskog razvoja te pojave mjerenja "kvalitete života" ponovno se otkriva i idealizira “tradicijski”, prema solidarnoj zajednici okrenut način života. Organiziraju se proslave unutar ruralnih i urbanih zajednica koje su pojedincima potrebne da bi se smanjila otuđenost u društvu (v. Kelemen; Škrbić Alempijević 2012: 56). U tom procesu značaju ulogu igraju plašiteljski i strahovni momenti nadnaravnih bića koji pospješuju oblikovanje i održavanje društvenih normi te stoga u predajama zauzimaju istaknuto mjesto (v. Honko 1962: 118, Mencej 2017: 390-394, Röhrich 2018: 353, Šešo 2016: 173-188).

Kako bi se pojasnila uloga straha i strašnog vezanog uz nadnaravna bića predaja koja se tematiziraju na festivalima, u radu se analizira najstariji hrvatski festival s temom predaja - Legendfest: festival legendi mitova i priča. Za potrebe analize provedena su 2017. terenska istraživanja na tri lokaliteta u Hrvatskoj (Lukavec, Pićan i Roški Slap) gdje se te godine festival organizirao. Rezultati istraživanja pokazuju da na takvim festivalima posjetitelji uz pomoć nadnaravnih bića predaja mogu lakše izraziti vlastite tjeskobe i nesigurnosti izazvane novim promjenama u društvu, iskazati vlastite strahove od nepoznatog te naznačiti aspiracije prema ekonomskoj stabilnosti. U tok kontekstu plašiteljska i strahotna uloga nadnaravnih bića predaja kroz koju se pojedinci uče suočiti sa svojim ograničenjima, životnim prijetnjama i nepredvidivim scenarijima i dalje je prisutna. Strašne scene i strašno koje je nerijetko prisutno u festivalskim programima dodatno privlače posjetitelje, a posebice mlađe generacije, jer se u kontroliranim okruženjima mogu suočiti sa strašnim (i strahom), od kojeg se mogu odmaknuti i na taj ga način naučiti nadvladati. Međutim, kada je riječ o nadnaravnim bićima predaja uz pojam strah 
treba vezati i pojam strahopoštovanje. U radu se ističe kako festivalski programi u kojima se posjetitelji susreću sa strašnim nadnaravnim bićima, pridonose stvaranju ili obnavljanju strahopoštovanja prema nadnaravnim bićima i njihovim moćima. Stvaranjem strahopoštovanja snaži i vjerovanje da su svojim moćima mogli, ali i da mogu, djelovati na svijet koji nas okružuje te se na taj način pospješuju traženje odgovora na brojna pitanja o kozmogoniji, ali i nama samima. Štoviše, provedeno istraživanje pokazuje da velik broj posjetitelja opisanih hrvatskih festivala prepoznaje upravo navedenu ulogu vjerovanja u nadnaravna bića. Posjetitelji kako su kod starijih naraštaja nadnaravna bića služila za tumačenje svijeta i životnih pitanja, ali ujedno ističu da i sami vjeruju u njihovo postojanje i poziciju unutar prirodnog poretka. Naime, želja za poznavanjem nadnaravnog, mitskog, fantastičnog, kao i popularni i znanstveni radovi koji izrastaju iz te želje "posebno bujaju u za zajednicu kriznim, prijelomnim vremenima" (Lozica 2007: 141). Proteklih smo desetljeća suočeni s onim što se može nazvati retradicionalizacijom društva i remitologizacijom suvremene kulture i znanosti (Lozica 2007: 149). U suvremenom hrvatskom društvu čovjek se stoga nastavlja nadahnjivati nadnaravnim bićima predaja kako bi opet formirao moralne norme i pravila ponašanja te uredio svijet u kojem živi. Interes za nadnaravnim bićima predaja zapravo je odraz težnji da se društvene probleme staviti pod kontrolu i da se oblikuje uređena svakodnevica.

Luka Šešo, Ph.D., Associate Professor, Catholic University of Croatia, Ilica 242, HR-10000 Zagreb, Croatia, luka.seso@unicath.hr 